\title{
Dynamics of Professional Interest \\ of Young Teachers as the Background of Professional Development
}

\author{
Irina S. Vatashchak* \\ Institute of Psychology of Development Practices \\ 50 Korneeva Str., Krasnoyarsk, 660001, Russia
}

Received 10.08.2015, received in revised form 27.08.2015, accepted 19.09.2015

The paper describes the results of the All-Russian Research of adaptation, consolidation and professional development of young teachers. It considers the concept of professional interest, its understanding and application in relation to teachers with 0-3 years' work experience, the opportunities to study professional interest and its dynamics. The study attempts to explore the dynamics of the interest depending on the experience, the characteristics of an educational institution, the regional system and policy in education both in the country and in every subject of the Russian Federation.

The data obtained after a thorough examination of the dynamics of professional interest, depending on various factors, may allow forecasting directions for the professional development of various groups of young teachers.

Keywords: professional interest, the dynamics of professional interest, professionalization, professional development, educational work, young teachers.

DOI: 10.17516/1997-1370-2015-8-11-2260-2274.

Research area: pedagogy, psychology.

The quality of teacher training, the severity of the selection of personnel for teaching and a teacher status are the key objectives of the personnel policy of the best educational systems in the world. The best schools are those whose heads understand that competitiveness is the sum of the quality levels of teachers themselves. The problems of the quality of teachers' work touch a variety of aspects that need consideration and analysis. Among them are the state and development trends of the teaching profession, particularly the issues relating to professional and career development in the field of education, the ideas of teachers themselves about their own professional prospects, methods and forms of professional development, as well as possible methods, technologies and institutes of work with students of teaching majors and young teachers who come to school (Mitrofanov, 2012). The question of the motivation of professional educational work and teachers' own professional interests is not least important in this list.

According to the study of 529 Moscow teachers with the experience of up to 5 years,

(c) Siberian Federal University. All rights reserved

* Corresponding author E-mail address: ira@ippd.ru 
$7.8 \%$ of them completely lost their interest in work within 5 years, while in the case of $48.3 \%$ of teachers the interest decreased (Ryabov, 2001). S.G. Vershlovskii presents similar results in his work. He points out that $10 \%$ of teachers with the experience of up to 3 years and $17 \%$ with the experience of 4-5 years plan to leave school (Vershlovskii, 2002, p. 38), a desire to stay and work in school of $40.3 \%$ of teachers has slightly decreased (Pochemu ..., p. 28).

The concept of "professional interest"1 is often used in the context of professional self-determination in choosing a profession. For example, the definition in an electronic psychological dictionary states: "Professional interests mean a selective activity towards an assumed profession; there are different levels of the interest in choosing a profession: a consumer's interest (contemplative interest arising in the first place under the influence from the outside), a worker's interest (increased activity, self-planning of the activity, the focus on the satisfaction with the process of activity, the awareness of one's success), and a professional interest itself (an informed desire to transform a certain activity into a profession, the understanding of the social significance of a profession, the autonomy and independence on the media and the situation)". The author discussed the options for professional selfdetermination related to the teaching profession in detail earlier (Khasan \& Vatashchak, 2014, p. 34). Professional self-determination is part of life self-determination. In other words, it is entering a particular social and professional group, a lifestyle and profession choice.

A deeper examination of the concept of "professional interest" allows referring it to the elements of the motivational-need sphere, which drive to master a variety of professional activities. Among other forms of motivation associated with the transformation of the object of activity are the professional interests on the mechanisms of emotional satisfaction associated not so much with the product or result of activity, as with the process. It is specific that their satisfaction does not lead to psychological saturation, as they are supported by inherently valued feelings of "being grasped".

Professional interests are developed in the context of leading activities peculiar to a particular stage of mental and professional development (R. Söll, D. Super). In this development they undergo a series of stages: the birth of individual interests, their registration in the subject context, the first formation of the system of interests (its amorphousness) and its crystallization, which is one of the main signs of professional sets' maturity. According to characterological theories, professional interests are understood as certain aspects of generic types of life (E. Spranger, J.L. Holland, E.A. Lichko). Reflexive processes related to the assessment of performance on socially predetermined samples are considered as the leading mechanisms in social approaches to the development of professional interests. Thus, for example, an interest can be regarded as a sense of competence in carrying out the activity that is more successful due to operational readiness (E.L. Deci, S.P. Smith, M. Gebhard), or as a learned standard of identification with other significant values (A. Bandura, V. Mitchell).

The discussion of the dynamics of specialists' professional interest in a particular area should be based on a more general, key concept of professionalization. Organizing and carrying out the study, we assumed that the origin of the word «professio» is related to the understanding of an intermediary function in society, and believed that professionalization is a category claiming to grasp the integrity of teacher education and work through the senses of the development of the profession and an individual professional growth. As a term in the most general sense, the word means "endowing with a profession". 
A professional in this case is the one who is endowed with and carries a status, a cultural norm embodied in knowledge. Becoming a professional in this sense means assigning a cultural norm, becoming its carrier.

Traditionally professionalization is viewed in the logic of psychological, sociological and pedagogical studies. The subject in this case is either an individual development in the professional field, or belonging to a certain professional community as a form of selfrealization in the course of professional activity.

Discussing the dynamics of professional interest, first of all, we analyze what exactly a specialist subjectifies in their activity at each point of time, what they consider significant, what draws their attention and what they plan to change. In fact, professional subjectivity rather than related essences and conditions, which often come to the fore for various reasons, are of interest. But due to the fact that in the early days of professional activity many moments, new requirements and essences concealed from the outside point of view, which a graduate could not even suggest, while a young professional faces in full, are identified, not all manage to think about professional interests in the true sense of the word. In most cases, young professionals are busy with the adaption to a specific workplace and profession as a whole, trying to understand what is happening around, which rules and regulations exist and try to act on the model.

Relying on the data from different studies (Banykina \& Stepanov, 2012, Mitrofanov et al., 2011), including our own pre-study undertaken earlier (Vatashchak, 2012), we can state that the current generation of teachers working at school definitely regard the idea of development as a value, but it is represented in a very reduced form: not by internal, qualitative and activity changes, but in the traditional form of following generally accepted norms, in the form of training and a gradual increase in knowledge. In other words, we can fix a routine understanding of development as the dynamics of accumulating experience in the majority of educators. According to this point of view, young teachers are inexperienced, inept, "under", while experienced teachers are mature, skillful and so on. It is assumed that the experienced do not need development; they have already developed, reached all, now they only need to fulfil the potential that they have gained. And the young treat development as increasing experience, gradual accumulation.

There is a different understanding of development in psychological science. On the one hand, it is an ontological understanding. When we talk about development in general, here, after L.S. Vygotskii, we mean subjects of mastering or emancipation: the exemption from ... immediately sets the opportunities for development - it is not a guarantee but a chance, an opportunity. The model developed by Larisa Maksimovna Mitina reflects this vision of development and involves a person's ability to go beyond a continuous flow of daily practice, to see their work as a whole and turn it into an object of practical transformation. Human professional development is determined by contradictions of various kinds. But the main driving force behind development of a professional is an intrapersonal contradiction between an acting self and a social self. The vector of professional development is a personality creative self (Mitina, 1997).

On the other hand, there is a technological definition of development: it means specific technological things happening within the boundaries of the known in culture, but with attribution to the character, which moves in the cultural field; in this sense, development is attributed to a person, but not an ontologeme. In other words, it is when a certain character masters what many others already know: "I can do it, and you still can not". In this sense, 
a person perceives their moving as development, but not in the sense of professionalism, because any profession is stable, it does not change. This definition may be illustrated by the matrix of professionalization, developed by a team headed by K.G. Mitrofanov. The development in it is supposed in the transition from level to level as an increase in freedom of action as the transition to the next level of freedom of professional action and a greater freedom of action. In other words, it is not just increasing experience and reducing anxiety or concern for discipline and other things, but qualitative changes in relation to the vision of profession (Mitrofanov et al., 2011).

In our opinion, supposing development in these two planes is adequate to the contemporary mission of the teaching profession in its various guises. After all, the situation of modern society and the rhythm of life require capabilities of rapid response, decision-making in situations of uncertainty, solving increasingly complex problems from man ... And it is school and therefore teachers who should prepare the younger generation for all these real-life situations.

In 2015, as part of the All-Russian Research of adaptation, consolidation and professional development of young teachers, one of the focuses of a special study was the dynamics of the professional interest of young teachers, depending on the experience and characteristics of an educational institution. The experts conducted a survey with the participation of 13,282 young teachers of all the subjects of the Russian Federation under the age of 35 years and with experience in educational institutions up to 3 years.

In order to study the dynamics of professional interest, depending on their experience, the experts carried out a comparative analysis of the responses of young teachers working in educational institutions of the country from 0 to 1 year; from 1 to 2 years; from 2 to 3 years. When answering the question: "Are you interested in educational work, in what area?", the experts distributed the respondents' opinions as follows (see Fig. 1). The respondents were offered 6 possible options: 1) communication with children; 2) subject and its teaching; 3) belonging to a community of teachers; 4) self-actualization; 5) extracurricular activities; 6) certainty, social guarantees; and here they were allowed to offer their own option (7) or tick Don't know (8).

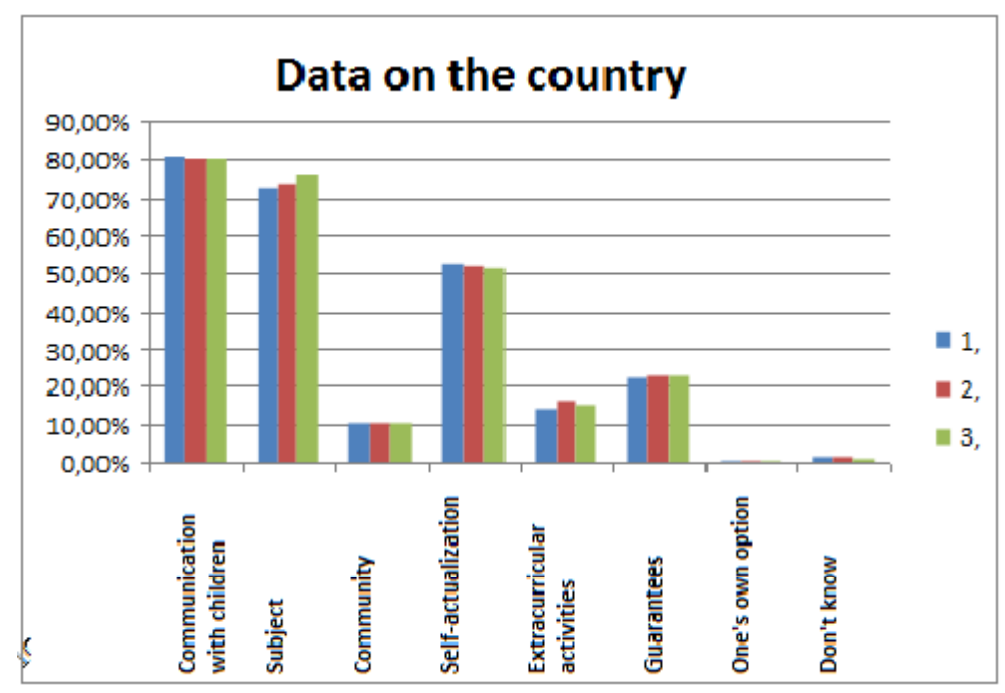

Fig. 1. Interest in educational work depending on experience 
We see that the interest in educational work of the teachers with experience from 0 to 3 years in educational institutions of the country is stable, without any significant differences, showing the dynamics of professional interest. This may be due to various reasons: 3 years of work are in some sense homogeneous, they do not represent any significant changes in professional interests of the majority of young teachers; the interest in the teaching profession of all teachers has some static characteristics in general and is not a dynamic entity because of the duration of experience.

The next question in the survey was "What is the focus of your attention today?". It was designed to detect the specific points of efforts and attention of young teachers with different work experience rather than common characteristics of work attractiveness and their interest in it. Answering this question, the respondents were expected to make no more than three choices of the following proposed options:

1. Adaptation to the educational institution;

2. Adaptation to the teaching profession;

3. Ability to communicate with children, to find common language with them;

4. Ability to eliminate deficiencies in the subject taught;

5. Teaching techniques and methods;

6. Ability to build relationship with parents;

7. Ability to find new knowledge and teach it to students;

8. Ability to work with documentation, reporting;

9. Upgrading the quality of teaching;

10. Increase in academic performance;

11. The search for resources for professional activities;

12. The absence of a horizon for development;

13. Difficulties in setting priorities;

14. Emotional stress with respect to your own incompetence;
15. Inability to realize creative initiatives and ideas.

Here, according to our hypothesis, we could detect a true situation of choice and, therefore, a genuine interest. The situation of the choice of three options from a variety of subjects, rolled into a pedagogical activity, simulates a real situation of choice in professional interest (if any), because it is impossible to pay an equally thorough and proper attention to all aspects. It is necessary to make a choice and channel your attention in order to achieve the intended results there, in order to "get rid of it," to make it your resource for further mastering of other skills and areas. "Choice is always a solution to the conflict. It is always both a preference and a denial at the same time. It is always both the adoption and implementation of responsibility at the same time" (Khasan, 1991, p.13).

The data on this subject are presented in Table 1 and in Fig. 2. The green color in the table denotes a statistically significant negative trend, the red one is used for a positive trend. The positive trend for three years is kept by: teaching technology and methods, upgrading the quality of teaching, ability to find new knowledge and teach it to students, academic performance; the positive trend for the first two years is kept by interaction with parents. The 3 points have a negative trend: adaptation to the profession, adaptation to the educational institution and communication with children. The following points do not have a statistically significant trend depending on work experience: work with documentation, reporting; ability to eliminate deficiencies in the subject taught; difficulties in setting priorities, the absence of a horizon for development, the lack of resources for activities, inability to realize creative initiatives and ideas, emotional stress with respect to your own incompetence.

Due to the fact that some answers have relatively low rates in the whole country, they 
Table 1. Distribution of the answers to the question "What is the focus of your attention today?" depending on experience

\begin{tabular}{|l|c|c|c|c|}
\hline & From 0 to 1 year & From 1 to 2 years & From 2 to 3 years & $\begin{array}{c}\text { More than } 3 \\
\text { years }\end{array}$ \\
\hline $\begin{array}{l}\text { 1. Adaptation to the educational } \\
\text { institution }\end{array}$ & $16,51 \%$ & $11,35 \%$ & $8,82 \%$ & $15,38 \%$ \\
\hline $\begin{array}{l}\text { 2. Adaptation to the teaching } \\
\text { profession }\end{array}$ & $39,66 \%$ & $23,79 \%$ & $15,03 \%$ & $15,38 \%$ \\
\hline $\begin{array}{l}\text { 3. Ability to communicate with } \\
\text { children }\end{array}$ & $42,09 \%$ & $38,00 \%$ & $36,28 \%$ & $30,77 \%$ \\
\hline 4. Subject & $19,38 \%$ & $22,33 \%$ & $21,89 \%$ & $3,85 \%$ \\
\hline 5. Teaching methods & $37,32 \%$ & $39,44 \%$ & $40,76 \%$ & $26,92 \%$ \\
\hline 6. Parents & $9,09 \%$ & $11,54 \%$ & $11,39 \%$ & $7,69 \%$ \\
\hline 7. Ability to find new knowledge $\%$ & $26,60 \%$ & $30,71 \%$ & $34,48 \%$ & $26,92 \%$ \\
\hline 8. Documentation & $24,21 \%$ & $23,89 \%$ & $23,49 \%$ & $30,77 \%$ \\
\hline 9. Quality of teaching & $31,55 \%$ & $37,35 \%$ & $42,40 \%$ & $38,46 \%$ \\
\hline 10. Academic performance & $22,48 \%$ & $26,37 \%$ & $27,94 \%$ & $38,46 \%$ \\
\hline 11. Resources for activities & $5,38 \%$ & $6,08 \%$ & $8,75 \%$ & $7,69 \%$ \\
\hline 12. Absence of a horizon & $1,02 \%$ & $1,23 \%$ & $1,29 \%$ & $0,00 \%$ \\
\hline 13. Priorities & $1,41 \%$ & $2,09 \%$ & $1,94 \%$ & $3,85 \%$ \\
\hline $\begin{array}{l}\text { 14. Emotional stress with respect } \% \\
\text { to your own incompetence; }\end{array}$ & $2,73 \%$ & $2,18 \%$ & $1,82 \%$ & $7,69 \%$ \\
\hline $\begin{array}{l}\text { 15. Inability to realize creative } \\
\text { initiatives and ideas. }\end{array}$ & $1,37 \%$ & $1,79 \%$ & $1,76 \%$ & $3,85 \%$ \\
\hline
\end{tabular}

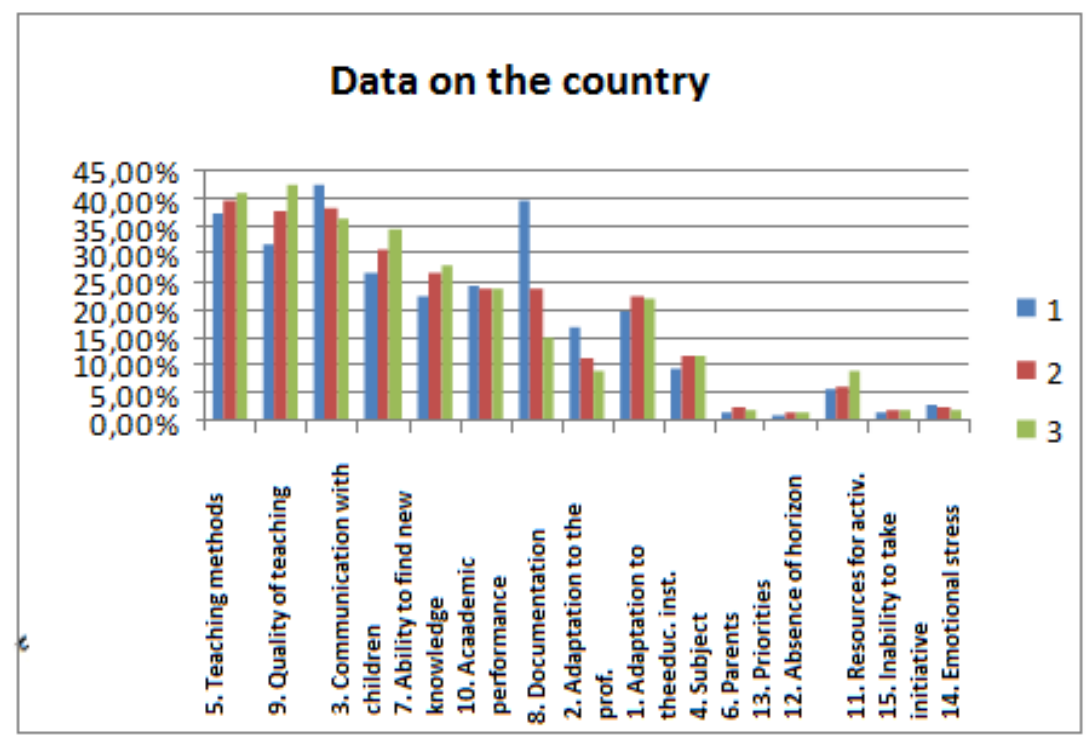

Fig. 2. Distribution of the answers to the question "What is the focus of your attention today?" depending on experience 
will not be taken for the further analysis. These are: 11) the search for resources for professional activities; 12) the absence of a horizon for development; 13) difficulties in setting priorities; 14) emotional stress with respect to your own incompetence; 15) inability to realize creative initiatives and ideas.

Para 1 - Adaptation to the educational institution - it suggests a start of a person in a particular educational institution with its structure, team, norms, traditions and so on. Finding one's own place by a person and identity with the organization where they work is an extremely important and necessary step at first. Nationwide, the figure has a negative trend; it is natural and desirable, as the process of adaptation is to be performed and attention is to be focused on other things, namely professional positioning and development.

Para 2 - Adaptation to the teaching profession - it involves the development of a profession as such, getting to know it from the inside, matching one's own expectations and reality, some adaptation and positing oneself as a teacher. This process is necessary and natural in the early years of being in the profession, but it also should decrease and end, opening up opportunities for other processes. Therefore, the observed negative dynamics according to the data of all interrogated young teachers of the Russian Federation is normal.

Para 3 - Ability to communicate with children, to find common language with them it involves interactive and perceptual aspects of the interaction between a teacher and children, the ability to communicate in general, regardless of the particular material. This criterion in the whole country has a negative trend (from $42.09 \%$ in the first year of work down to $36.28 \%$ in the third year). This fact suggests that the fundamental ability to communicate is mastered, and gradually the attention to it is reduced, at the same time it does not disappear completely in the structure of interest. This is normal, as the area of interest in interaction with children should move to more concrete and meaningful things for example, being able to find new knowledge and teach it to students (para 7), the increase in academic performance (10).

Para 4 - Ability to eliminate deficiencies in the subject taught - it is aimed at the detection of the fact whether young teachers regard the lack of knowledge in the subject as a deficiency, whether they feel the lack of knowledge of the subject area that they received during the training, and whether the elimination of these gaps is a subject of special work. According to the data obtained in the Russian Federation, this figure does not have distinct dynamics, and judging by the number of ticks, it is of a moderate importance ( $20 \%$ of ticks compared with, for example, $40 \%$ of teaching techniques). This may indicate that only $20 \%$ of young teachers, regardless of their experience, feel deficiencies in the taught subject and try to eliminate them.

Para 5 - Teaching techniques and methods it includes a focus on how to teach, in contrast to the previous para, saying what to teach. It is supposed to detect whether young teachers focus their attention on teaching techniques and methods, diverse forms and techniques, or leave it till a later professional period. It was revealed that this criterion has sufficiently high figures in comparison with the others $(40 \%)$ and statistically significant positive dynamics in the country.

Item 6 - Ability to build relationship with parents - it is a separate category, as it is fundamentally different from all other types of pedagogical actions and often causes great difficulty and stress in young professionals. The ability to build constructive relationship with parents by a type of cooperation and mutual solidarity and compromise is an extremely important characteristic of a young teacher. This 
indicator in the country has positive dynamics from the first to the second year of experience, in the third year it remains at the same level and has the lowest level $(10 \%)$ in comparison with other analyzed characteristics.

Para 7 - Ability to find new knowledge and teach it to students - it contains 2 content cores it is both the ability to "take" knowledge and the idea to convey this ability, this method to students. An uncommon content together with being turned towards both to oneself and to another person hide behind apparent typicality of the statement. The idea of discovering the ways to find existing knowledge rather than transferring it is laid in this criterion. Distinct positive dynamics is found throughout the country, the response rate is higher than the average (30\%). This means that young teachers focus on finding the ways to search for new knowledge and the methods to transfer these ways to students.

Para 8 - Ability to work with documentation, reporting - it summarizes the formal aspect of the teacher's work, which takes a significant share of time and effort in the present situation according to the estimation of employees in the educational sphere. The data obtained in the study is without any dynamics depending on work experience in the whole country, but corresponds to the average rate (23\%); in other words, the figure is higher than some others, for example, interaction with parents, by the degree of attention.

Para 9 - Upgrading the quality of teaching it is another characteristic, aimed at the competences of a teacher. It reveals if a teacher detects and subjectifies what and how they teach in terms of upgrading quality, increasing efficiency, whether a teacher sees this as a place where they can apply their own efforts. As for this indicator, we revealed a positive trend, from $31 \%$ in the first year of work to $42 \%$ in the third year that is seen with the naked eye. Thus, for maximum indicators, it is the most frequently ticked para.
Para 10-Increase in academic performanceis linked with the formal requirements for measuring the quality of education, i.e. the assessments that students have. Obviously, this is the most formal, visible and measurable criteria; neither teachers nor students can ignore it. Naturally, the performance draws attention of all employees of educational institutions. The data on the country shows a statistically significant positive trend, the rate of indicators is the average (23\%). This suggests that over time at school, teachers take more interest in the issues of academic performance.

Thus, in relation to the professional dynamics of young teachers, depending on their work experience in an educational institution, we can say that the focus of their attention in the first year is on the adaptation to the profession and finding "common language" with children, by the beginning of the second year a teacher starts to take interest in the quality of teaching and the ability to find new knowledge and teach it to children, and by the beginning of the third year the issues of the quality and techniques and methods of teaching clearly begin to dominate. In other words, the detected dynamics can be described as "from the general to the special ", from getting introduced to the profession in general to the specific (substantive, not formal) techniques and skills (see Fig. 3).

We also conducted focus groups, in which 7847 young teachers took part, in all the subjects of the Russian Federation.

According to the data obtained by a method of a directive interview, we disclosed a professional interest's structure of young teachers of the Russian Federation with 0-3 years' work experience and an understanding of its dynamics, depending on various factors by young professionals themselves.

As already clarified, discussing a professional interest, first and foremost, you need to figure out 


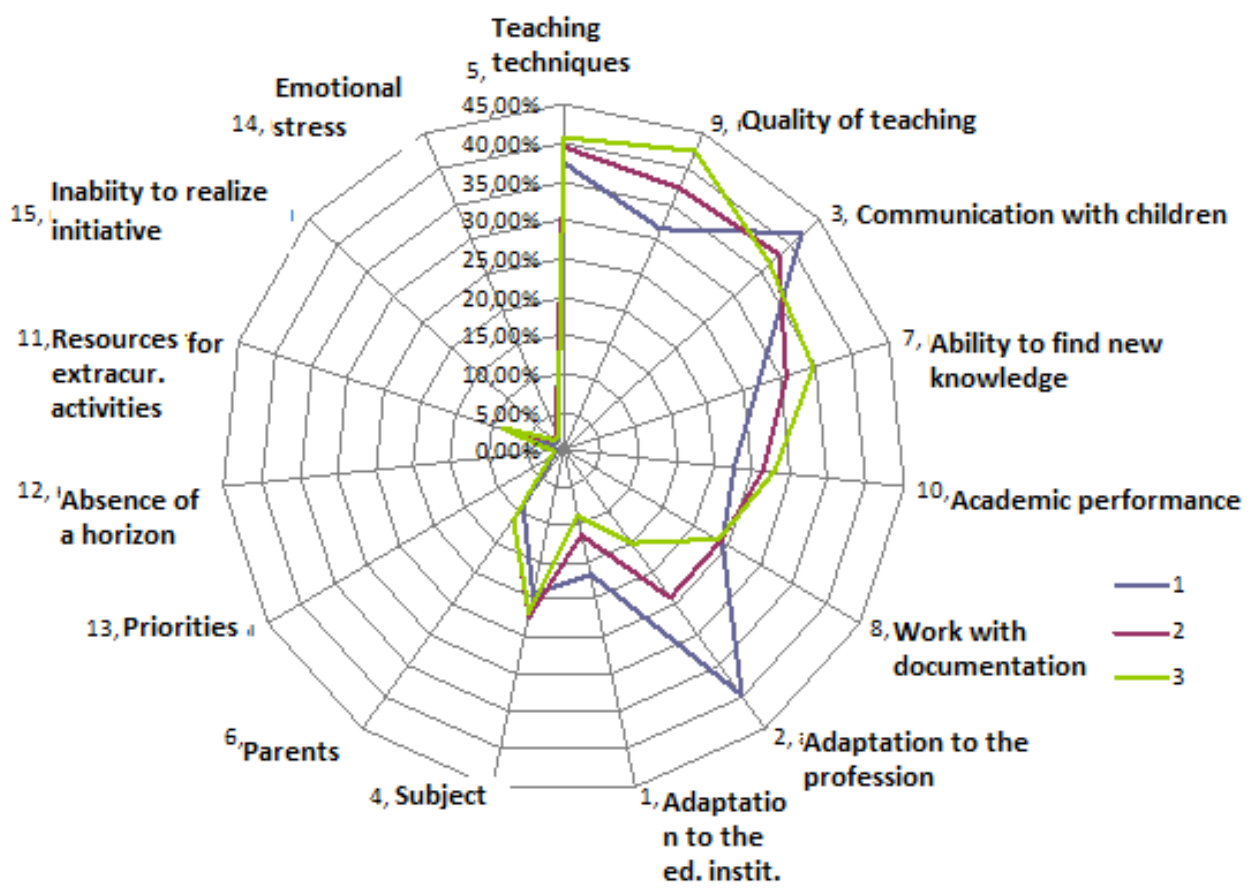

Fig. 3. Distribution of the answers to the question "What is the focus of your attention today?" depending on experience

what exactly a professional subjectifies in their activities, which they consider significant, what draws their attention, in relation to what they plan to change and evolve. Since the key interest is the professional subjectivity, analyzing and interpreting the focus groups, we missed the data for all confounding factors.

During their participation in the focus groups the respondents made 5280 statements relating to their personal professional interest. All of these statements in the processing of the data were divided into the four major categories that define different types of professional interest, namely:

Subject area and its development which involve broadening and deepening one's own knowledge in the subject area, which the teacher deals with; the interest in it not only as a subject of teaching, but also as an inherent value.

Interaction with children is a key feature, which distinguishes educational work from all others. This is an attention to interaction itself, to its types, methods, techniques, means, results and so on; the focus on children and students in the work.

The range of professional positions which means expanding professional opportunities through developing and taking other positions, in addition to a teacher's one. It also includes the idea of vertical and horizontal mobility.

Personal growth that is fixing changes in yourself as a person and as a professional, increasing general social and professional competences; the idea of continuous selfdevelopment.

The quantitative distribution of all the responses is reflected in Fig. 4.

In the subsequent processing of the data in each of the selected categories the following responses were divided into two parts: those that really characterize the area of professional 


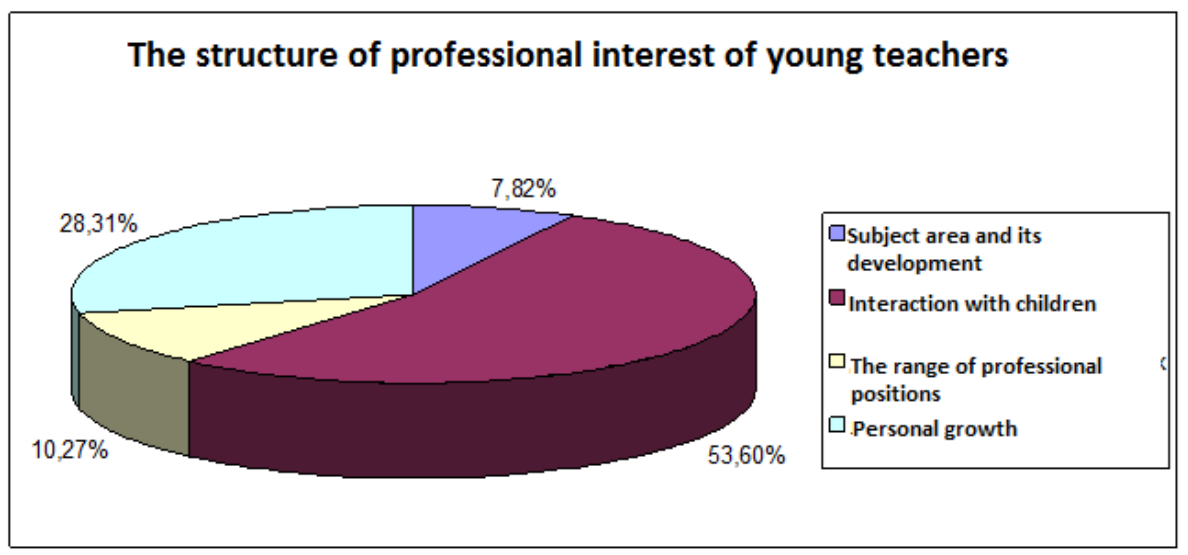

Fig. 4. The number of responses of young teachers for each category of professional interest, as percentage, data on the Russian Federation

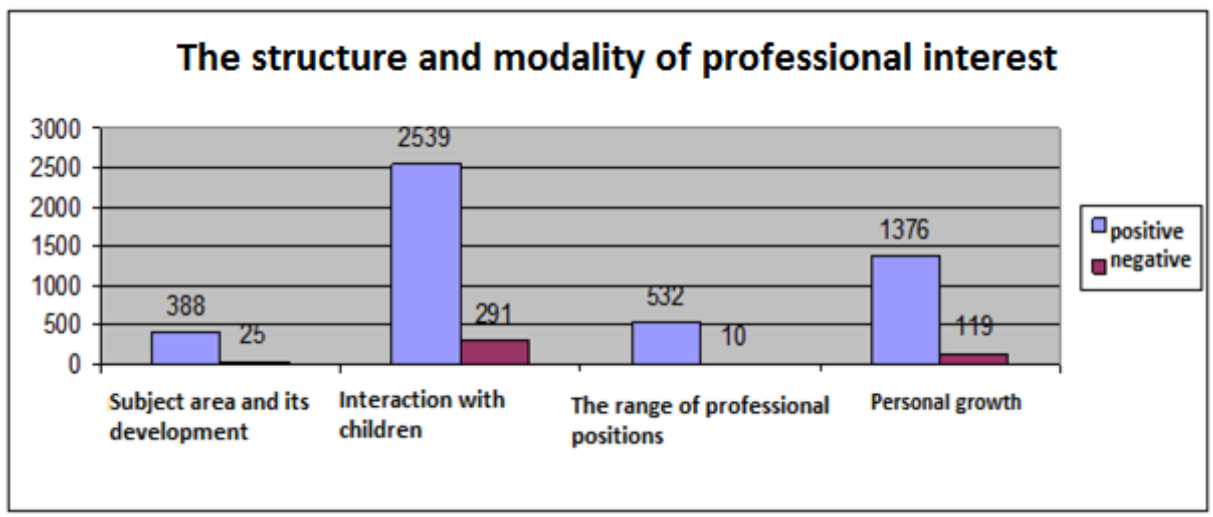

Fig. 5. The number of responses of young teachers for each category of professional interest on the modality and the number of statements, data on the Russian Federation

interest and efforts of a young specialist, and those that describe an area of interest of a teacher, but in respect of which they do not take real actions or efforts for various reasons. The first group of responses was arbitrarily designated as "positive", the second - as "negative", which thus describes the modality of the attitude of the respondents to the items of professional interest. The distribution of their responses is shown in Fig. 5.

In order to determine the natural character of frequencies of variables that were obtained by calculating the number of observations that fall under different categories, we used the associative test $\chi 2$.

$\chi 2 E m p=46.493$. Critical values data $\chi 2$ with $\mathrm{v}=3$

\begin{tabular}{|c|c|c|}
\hline \multirow{2}{*}{$\mathbf{v}$} & \multicolumn{2}{|c|}{$\mathbf{p}$} \\
\cline { 2 - 3 } & 0.05 & 0.01 \\
\hline 3 & $\mathbf{7 . 8 1 5}$ & $\mathbf{1 1 . 3 4 5}$ \\
\hline
\end{tabular}

Since $\chi 2$ Emp exceeds a critical value, it was found that the differences between the distributions are statistically significant, in other words, the frequency of an encountered feature is not random, links have a natural character. 
Table 2. Calculation of indicators to verify the statistical significance between the indicators

\begin{tabular}{|c|c|c|c|c|c|}
\hline $\mathrm{N}$ & $\begin{array}{c}\text { Empirical } \\
\text { frequency }\end{array}$ & $\begin{array}{c}\text { Theoretical } \\
\text { frequency }\end{array}$ & $\left(f_{\mathrm{e}}-f_{\mathrm{t}}\right)$ & $\left(f_{\mathrm{e}}-f_{\mathrm{t}}\right)^{2}$ & $\left(f_{\mathrm{e}}-f_{\mathrm{t}}\right)^{2} / f_{\mathrm{t}}$ \\
\hline 1 & 388 & 378.19 & 9.81 & 96.24 & 0.254 \\
\hline 2 & 25 & 34.81 & -9.81 & 96.24 & 2.765 \\
\hline 3 & 2539 & 2591.49 & -52.49 & 2755.2 & 1.063 \\
\hline 4 & 291 & 238.51 & 52.49 & 2755.2 & 11.552 \\
\hline 5 & 1376 & 1369 & 7 & 49 & 0.036 \\
\hline 6 & 119 & 126 & -7 & 49 & 0.389 \\
\hline 7 & 532 & 496.32 & 35.68 & 1273.06 & 2.565 \\
\hline 8 & 10 & 45.68 & -35.68 & 1273.06 & 27.869 \\
\hline Totality & 5280 & 5280 & - & - & 46.493 \\
\hline
\end{tabular}

In other words, both the distribution between the categories and the evaluation modality that is a positive or negative attitude to professional interest have statistical significance under the current sample.

The qualitative interpretation of the data obtained was carried out for each category.

The most common point of professional interest is the interaction with children $53.6 \%$ of all the responses. The wording of this paragraph is utterly general and should be carefully specified. Hypothetically, for the interpretation the researchers suggested the following points:

- Coming in an emotional contact with children;

- Establishing a business relationship with students;

- Retention of discipline in class;

- Improvement of formal indicators of mastering an educational program;

- Formation and monitoring of learning outcomes (content) of students;

- Educational process.

In the data processing a hypothesis about the structure of the professional interest of young professionals in the field of interaction with children was confirmed and clarified.
Young professionals pay most of their attention to coming in both an emotional and business / professional contact and relationship with children.

The next most frequently mentioned point, which many young teachers subjectify in their interaction with children, is the educational process.

Another special point in the category of "interaction with children" is forming learning outcomes. In fact, this includes both formal and substantial characteristics highlighted in the development of a research scheme: the improvement of formal indicators of mastering an educational program and the formation and monitoring of learning outcomes (content) of students.

The last major point in this category, which occurs less frequently, was the retention of discipline in class. Not all young professionals can effectively organize a situation in class as they would like. Basically, the questions of discipline are raised by the respondents who feel their deficiencies in this area.

Coming in a contact and effective communication with children, of course, is an essential side that differs educational work from many others, so it is important and requires 
maximum attention of all the teachers, young teachers in particular. Here, young professionals, on the one hand, are in a more difficult situation, because do not have enough experience and their own observations; they may have received less necessary knowledge about the psychology of children's ages in the learning process; and on the other hand, they are in a more favourable situation, because remember their own childhood better, they are closer to children by their occupation and hobbies and, most importantly, children consider and perceive them as much closer people, able to understand and become a significant adult.

Naturally, young professionals pay more than half of their attention and effort to the interaction children in its various forms, since it is one of the conditions for a comfortable, desirable position in the profession.

The next largest category for the analysis of professional interest was personal growth. $28.31 \%$ of all the responses are about it. This point appeared to include existing and planned changes in connection with the profession both in the area of own professional competences and personal skills and qualities, as well as universal, general social competences.

The responses here are as follows:

- Going through formal procedures;

- Personal growth by itself;

- Improving the educational level;

- Professional development;

- The lack of prospects.

For many respondents increasing their own competences is significant and important both for the development in the profession and for personal development and growth. This is a significant and positive factor, as such specialists regard their profession not only as a place where they lay themselves out, use efforts and give their all to students, but also as a place of their personal progress, self-enrichment, a desired part of life.
The third category that is not as large as the previous ones $(10.27 \%$ of all the responses) is a range of professional positions. This feature is related to the modern trends in education and a gradual change in its structure. A modern teaching profession has moved far from the traditional ideas that teacher's labour is the work at the blackboard in class. Modern Teacher is an employee capable of performing a varied list of types of work from a home caregiver to an education manager and a professional in the field of educational law; from a developer of new educational content to a specialist in the implementation of educational projects; from a developer and technologist of educational tests to an expert in the implementation of individual programs related to a child's specific abilities. In fact, a professionally trained teacher ceases to be a key figure in education.

The young teachers who participated in the focus groups, following modern trends, paid attention to this issue as well. Perhaps, yet not in such a wide scale, the idea to be engaged in the same activities for all professional life attracts only a few respondents who consider it basically possible in the current situation.

Thus, the current ideas of the profession and the career differ significantly from the views on the promotion, prevailing in the domestic theory and practice of human resource management a decade ago. If earlier people mastered one profession, and this was enough almost for the entire period of professional activity, now a quick change of specialization followed by constantly emerging new demands of the market is required. A repeated change of organizations of employers has become a norm rather than an exception for most people. The statement saying "one life - one organization - one profession - one career" is out of date. It was replaced by the idea of variability and multi-vector nature in career. An employee can develop their career by acquiring the 
necessary competence that would allow them to take new and higher positions in the organization and reach a fundamentally different level of responsibility.

The last, that is the smallest category in the area of professional interest, is the subject area and its development $-7.82 \%$ of the total number of responses. Before the study it could not be assumed that this category would be less interesting for young professionals. Basically, it includes the responses related to filling in the blanks in the taught subject, which were found in their own background after a start in the educational institution; but there are also a small percentage of the responses related to the substantial development of the area, its deeper examination and acquirement.

We see that few surveyed young teachers with 0-3 years' work experience pay much attention to the actual subject and its development; apparently, it is not very significant in comparison with other things, as either it is considered as already available at a sufficient level, or not considered as something that requires effort and can be changed, therefore, as something that is not considered as mine.

Summarizing the data obtained through the focused interview, in the dynamics of young teachers' professional interest we see that the greatest attention is paid to children and building interaction with them, followed by personal growth and increasing professional and social competences, followed by the development of other professional positions (most often of teacher's ones as well), followed by the subject area and its development.

We know that any subject taught by the teacher (science projection or its derived part a scientific theory - in a school curriculum) is to be transmitted as a sequence of "held" lessons. Thus, a young teacher faces a task to keep the integrity and scientific "picture" of the subject, save all its internal communications, its structure without breaking it down or "spilling" it into fragments of individual facts, terms and concepts. But the drama of the situation for a young teacher is in the fact that only now after starting to teach a subject to their students, they realize that this is only possible if you have your own ideas about the structure and the "field" of the subject (the knowledge of the state standard of educational content is a necessary but not sufficient condition).

In this regard, according to the information received, the young teachers of the Russian Federation with 0-3 years' work experience focus their attention on teaching and interaction with children rather than on the subject; on the one hand, it indicates that the subject is already "automated" and minimized for them, but judging by the detailed responses, which they use to characterize the development of the subject area, another hypothesis is also true, that is, young professionals have not understood yet how important it is to keep the integrity of the subject in the beginning, in other words, it means seeing a lesson (local) organization of the transfer of knowledge in conjunction with an integrated structure of the subject in order to "automate" the teaching of the subject in some measure in the future and to focus on the work with the class, but not on the subject material itself.

The early years are a fundamental period of the formation for a start in the profession. Obviously, at the beginning of the professional work a teacher (a subject teacher in particular) is characterized by the concentration mostly on one focus of their career. In the process of professional development, the number of focuses kept in attention will increase.

Derives from the Latin words Profiteor that is declaring one's own trade and interest that is important 


\section{References}

Banykina, S.V. \& Stepanov, E.I. Konflikty v sovremennoi shkole: izuchenie i upravlenie [The conflicts in the modern school: study and control]. Moscow, 2012.

Khasan, B.I. \& Vatashchak, I.S. (2014). Protivorechiia interesov i tselevykh ustanovok $\mathrm{v}$ professional'nom samoopredelenii [Conflicts of interests and goal sets in professional selfdetermination]. Sociology, 4, 32-39.

Khasan, B.I. Nepreryvnoe obrazovanie: opyt, problemy, perspektivy [Continuing education: experience, problems, prospects]. Interuniversity collection of scientific papers, Krasnoyarsk, 1991.

Mitina, L.M. (1997). Lichnostnoe i professional'noe razvitie cheloveka v novykh sotsial'noekonomicheskikh usloviiakh [Personal and professional development of man in the new socio-economic conditions]. Questions of psychology, 4, 28-38.

Mitrofanov, K.G. Sovremennye instituty i tekhnologii professionalizatsii uchitelia v sisteme nepreryvnogopedagogicheskogoobrazovaniia [Modern institutes and technology of professionalization of teachers in continuing teacher education]. Krasnoyarsk, 2012. 316 p.

Mitrofanov, K.G., Vasil'eva, N.P. \& Kozyreva, E.Iu. Problemy professionalizatsii rabotnikov obrazovaniia: vvedenie $\mathrm{v}$ problematiku [The problems of professionalization of educators: introduction to the topic]. Proceedings of the 17th All-Russian Research-to-Practice Conference in Krasnoyarsk, April 2010. Krasnoyarsk, KKIPK, 2011.

Pochemu pedagogicheskii? Beseda s dotsentom KGPU Sergeem Grippa [Why teaching? Interview with Associate Professor Sergei Grippa, KSPU]. Electronic resource, available at: http:// praktika.karelia.ru/gazeta/gazeta_12/g_12 $\mathrm{ml} /$

Ryabov, V.V. et al.. Molodoi uchitel': problemy, adaptatsiia, stanovlenie: Inform.-analit. biul. po rezul'tatam monitoringovogo issled. $v 10$ ucheb. okrugakh g. Moskvy [The young teacher: problems, adaptation, formation: research and information bulletin on the results of a monitoring study in 10 educational districts of Moscow]. Mosk. org. profsoiuza rabotnikov narod. obrazovaniia i nauki RF, Moscow, Moskow City Pedagogical University Press, 2001.

Vatashchak, I.S. Proektirovanie i obespechenie professional'nogo razvitiia molodykh pedagogov. Psikhologiia obrazovaniia: sostoianie i perspektivy [Designing and providing the professional development of young teachers. Educational psychology: status and prospects]. Proceedings of the Second Conference of Educational Psychologists of Siberia in Irkutsk, 27-30 June 2012, Ed. Barkov N.P. Irkutsk, Irkutsk State University Publishing House, 2012.

Vershlovskii, S.G.Pedagogepokhiperemen, ili Kakreshaiutsia segodniaproblemyprofessional'noi deiatel'nosti uchitelia [The teacher of changing times, or How the problems of professional work of the teacher are solved today]. Ed. M.A. Ushakova. Moscow, Sentiabr', 2002. 


\title{
Динамика профессионального интереса \\ молодых учителей как основа \\ для профессионального развития
}

И.С. Ватащак

Институт психологии практик развития Россия, 660001, Красноярск, ул. Корнеева, 50

\begin{abstract}
В статье описываются результаты всероссийского исследования адаптаџии, закрепления u профессионального развития молодых педагогов. Рассматривается понятие профессионального интереса, его понимание и применение в отношении учителей со стажем от 0 до 3 лет, возможности изучения профессионального интереса и его динамики. В исследовании предприняты попьтки изучения динамики интереса в зависимости от стажа, особенностей образовательного учреждения, региональной системы и политики в области образования как в целом по стране, так и в каждом субъекте Российской Федерации.

Данные, полученные в результате пристального рассмотрения динамики профессионального интереса в зависимости от различных факторов, могут позволить прогнозировать направления профессионального развития различных групп молодых учителей.
\end{abstract}

Ключевые слова: профессиональный интерес, динамика профессионального интереса, профессионализация, профессиональное развитие, педагогическая деятельность, молодые педагоги.

Научная спещиальность: 13.00.00 - педагогические науки, 19.00.00 - психологические науки. 